\title{
Bmi-1 promotes the invasion and migration of colon cancer stem cells through the downregulation of E-cadherin
}

\author{
ZEFENG ZHANG ${ }^{1,2}$, XIAOLING BU ${ }^{2}$, HAO CHEN $^{2}$, QIYI WANG ${ }^{2}$ and WEIHONG SHA ${ }^{2}$ \\ ${ }^{1}$ Shantou University Medical College, Shantou, Guangdong 515041; ${ }^{2}$ Department of Gastroenterology, \\ Guangdong General Hospital, Guangdong Academy of Medical Sciences, Guangzhou, Guangdong 510080, P.R. China
}

Received February 24, 2016; Accepted September 1, 2016

DOI: $10.3892 / \mathrm{ijmm} .2016 .2730$

\begin{abstract}
Metastasis and recurrence are the challenges of cancer therapy. Recently, mounting evidence has suggested that cancer stem cells (CSCs) and epithelial-mesenchymal transition (EMT) are critical factors in tumor metastasis and recurrence. The oncogene, Bmi-1, promotes the development of hematologic malignancies and many solid tumors. The aim of the present study was to elucidate the mechanisms through which Bmi-1 promotes the invasion and migration of colon CSCs (CCSCs) using the HCT116 colon cancer cell line. Sphere formation medium and magnetic-activated cell sorting were used to enrich and screen the CCSCs. CD133 and CD44 were regarded as markers of CCSCs and they were found to be co-expressed in the HCT116 colon cancer cell line. Colony formation assay, cell proliferation assay and viability assay using the Cell Counting Kit-8, and transplantation assay using nude mice injected with CCSCs were used to examine the CCSCs. The CD133 ${ }^{+} \mathrm{CD} 44^{+} \mathrm{HCT} 116$ cells exhibited greater cloning efficiency, an enhanced proliferative ability, increased cell viability and stronger tumorigenicity; these cells were used as the CCSCs for subsequent experiments. In addition, the invasive and migratory abilities of the $\mathrm{CD} 133^{+} \mathrm{CD} 44^{+} \mathrm{HCT} 116$ cells were markedly decreased when Bmi-1 was silenced by small interfering RNA (siRNA). The results of RT-qPCR and western blot analysis suggested that Bmi-1 had a negative effect on E-cadherin expression. On the whole, our findings suggest that Bmi-1 promotes the invasion and migration of CCSCs through the downregulation of E-cadherin, possibly by inducing EMT. Our findings thus indicate that Bmi-1 may be a novel therapeutic target for the treatment of colon cancer.
\end{abstract}

Correspondence to: Dr Qiyi Wang or Dr Weihong Sha, Department of Gastroenterology, Guangdong General Hospital, Guangdong Academy of Medical Sciences, 106 Zhongshan Second Road, Guangzhou, Guangdong 510080, P.R. China

E-mail: qiyiw@163.com

E-mail:wh-sha@163.com

Key words: Bmi-1, HCT116 cells, colon cancer stem cells, E-cadherin, metastasis

\section{Introduction}

Colorectal cancer (cancer of the colon and/or rectum) is the second leading cause of cancer-related mortality in the US according to the National Comprehensive Cancer Network (NCCN) in 2015 (1). It has been reported that in $15-25 \%$ of patients with colorectal cancer, hepatic metastasis has already occurred prior to diagnosis and metastasis occurs in more than half of the patients with this disease. Although the 5-year survival rate of patients with colon cancer following radical surgery is often $>50 \%$, this decreases to $<12 \%$ with the occurrence of metastasis $(2,3)$. Metastasis has thus become the key obstacle to the effective treatment of colon cancer and remains a big challenge for clinicians due to the wide disparities in survival rates.

The cancer stem cell (CSC) theory is a new theory which has appeared in recent years as regards the occurrence, development, metastasis and recurrence of tumors. CSCs are defined as a subpopulation of cancer cells which have the characteristics of self-renewal, differentiation abilities, metastatic potential and the ability to resist conventional chemoradiotherapeutics (4-6). The discovery of markers of CSCs has facilitated the screening and studying of a number of types of cancer, including leukemia, brain cancer, breast cancer, abdominal cancer and cancers of the reproductive system (7-15). CD133 and CD44 are considered markers of the surface membrane of cells and have been used to identify colon CSCs (CCSCs) (11-13) and have been recently reported to be co-expressed in colon cancer with hepatic metastases (16).

Epithelial-mesenchymal transition (EMT) is considered to occur during cancer invasion and migration, or tumor progression. In this process, epithelial cells lose their epithelial characteristics and adopt a mesenchymal-like appearance or characteristics $(17,18)$. The downregulation or loss of E-cadherin, a transmenbrane protein important for cell-cell junctions, is treated as the hallmark of EMT (19). Since CSCs and EMT both play significant roles in cancer development, understanding the link between them may enhance our knowledge of the pathogenesis and mechanisms responsible for metastasis in cancer.

The polycomb group ( $\mathrm{PcG}$ ) of proteins are a family of transcriptional repressors that orchestrate alterations in chromatin structure to regulate gene activity $(20,21)$. A number of PcG proteins have been confirmed to be altered in human cancers, 
such as Bmi-1 (22-24). Bmi-1 is known as transcriptional repressor targeting the Ink4a/Arf gene locus, and has also been described as an oncogene in many solid tumors, playing a critical role in the maintenance of CSCs (25). However, the role of Bmi-1 in the functions CCSCs has rarely been reported, at least to the best of our knowledge.

In our previous study (26), we found that the expression of Bmi-1 in colon cancer tissues closely correlated with the clinical stage, invasion depth and metastatic ability of the tumors. In the present study, we screened and identified CCSCs using the HCT116 colon cancer cell line. We also wished to determine the role that Bmi-1 plays in CCSCs and to elucidate the underlying mechanisms. It would be of clinical and therapeutic significance to provide a novel target for colon cancer therapy.

\section{Materials and methods}

Cell line and cell culture. The HCT116 colon cancer cell line was obtained from the Cell Bank of the Committee on Type Culture Collection of the Chinese Academic of Science (CCTCC; Shanghai, China). The cells were cultured in RPMI-1640 (Corning Inc., Corning, New York, NY, USA) supplemented with $10 \%$ fetal bovine serum (FBS; Gibco-BRL, Grand Island, NY, USA)at $37^{\circ} \mathrm{C}$ with $5 \% \mathrm{CO}_{2}$. The culture conditions for the HCT116 cells to form tumor spheres in suspension were as previously described (27-29). The sphere formation medium (SFM) used was RPMI-1640 supplemented with $20 \mathrm{ng} / \mathrm{ml}$ basic fibroblast growth factor (bFGF) and $20 \mathrm{ng} /$ ml epidermal growth factor (EGF) (both from PeproTech, Inc., Rocky Hill, NJ, USA), 2\% B27 (1:50 dilution; Gibco-BRL), and $0.4 \%$ bovine serum albumin (BSA; Invitrogen Life Technologies, Carlsbad, CA, USA). Enzymatically dissociated single cells were diluted to a density of $2 \times 10^{4} / \mathrm{ml}$ and gradually replaced with SFM after plating into $24-w e l l$ plates. The cells were cultured in an incubator at $37^{\circ} \mathrm{C}$ with $5 \% \mathrm{CO}_{2}$.

Flow cytometry. The HCT116 cells cultured in SFM were washed twice with phosphate-buffered saline (PBS; Corning, Inc.) and resuspended in PBS at a density of $1 \times 10^{7}$ cells $/ 100 \mu \mathrm{l}$. The dissolved cells were stained using anti-human CD133-PE antibody (1:10 dilution; Miltenyi Biotec $\mathrm{GmbH}$, Bergisch Gladbach, Germany) [no need for cells after magnetic-activated cell sorting (MACS)], and anti-human/mouse CD44 antibody (1:50 dilution; eBioscience, Inc., San Diego, CA, USA), followed by incubation for $20 \mathrm{~min}$ on ice and subsequent washing with PBS again twice. The respective isotype controls were used at the same concentrations according to the manufacturer's instructions (eBioscience, Inc.). The cells were analyzed on a flow cytometer (FACSVerse; BD Biosciences, Franklin Lakes, NJ, USA) at the Sun Yat-Sen Memorial Hospital of the Sun Yat-Sen University (Guangzhou, China).

MACS. The HCT116 cells cultured in SFM were resuspended in PBS with $2 \%$ FBS to a total volume of $1 \mathrm{ml}$ at a density of $1 \times 10^{8}$ cells $/ \mathrm{ml}$ in a $12 \times 75 \mathrm{~mm}$ polystyrene tube to properly fit into the magnet (EasySep; STEMCELL Technologies, Inc.). This was followed by the addition of $100 \mu \mathrm{l}$ anti-human CD32 (Fc $\gamma \mathrm{RII})$ blocker, $50 \mu \mathrm{l}$ of antihuman CD133-PE, $100 \mu \mathrm{l}$ of PE selection cocktail and $50 \mu \mathrm{l}$ of magnetic nanoparticles in turn according to the manufacturer's instructions (EasySep). The cell suspension was then brought to a total volume of $2.5 \mathrm{ml}$ by the addition of PBS with $2 \%$ FBS (Step A). The tube was then placed into the magnet for $5 \mathrm{~min}$ and the supernatant fraction was poured off (Step B). Steps A and B were repeated twice. The magnetically labeled cells remained inside the tube and held by the magnetic field of the magnet. The cells in the tube were then used flow cytometric analysis or other assays.

Colony formation assay. In total, numbers of 50/100/

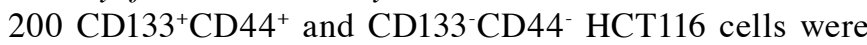
seeded in each well in 6 -well plates. The medium was discarded when colonies were observed by the naked eye. The colonies were fixed in methanol and stained with 10\% Giemsa (Teaching and Research Section of Pathology of Shantou Medical College, Shantou, China). A microscope (Leica DMI, Leica Microsystems Inc., Buffalo Grove, IL, USA) was used to confirm that the colonies were made up of $>50$ cells and to measure the diameters.

Cell Counting Kit-8 (CCK-8) assay for the analysis of cell proliferation and cell viability. One hundred microliters of suspension (RPMI-1640 only, CD133 ${ }^{+} \mathrm{CD} 44^{+}$and CD133-CD44- HCT116 cells) was respectively plated in 96-well plates and cultured for approximately $4 \mathrm{~h}$ until the cells had completely attached to the bottom of the wells. The cells were cultured at a population of 1,000, 2,000, 4,000 and 8,000 cells per well. Subsequently, $10 \mu \mathrm{l}$ of 2-(2-methoxyl-4nitrophenyl)-3-(4-nitrophenyl)-5-(2,4-disulfophenyl)-2H-tetrazolium, monosodium salt (WST-8; (Dojindo Molecular Technologies Inc., Kumamoto, Japan) were added to each well followed by incubation at $37^{\circ} \mathrm{C}$ for approximately $4 \mathrm{~h}$. The absorption (OD value) was read at $450 \mathrm{~nm}$ using a spectrophotometer (Multiskan GO; Thermo Fisher Scientific, Inc., Waltham, MA, USA). The OD values were corrected after the value of the control (cells cultured in RPMI-1640 only) was subtracted. To examine cell viability, 8,000 cells were used from each group, and the experiment was repeated 30 times. Cell proliferation and viability assays were performed by CCK-8 assay as previously described (30-34).

Tumor transplantation assay using BALB/c-nu/nu mice. $\mathrm{CD} 33^{+} \mathrm{CD} 44^{+}$and CD133-CD44- $\mathrm{HCT} 116$ cells were trypsinized, pelleted and resuspended in RPMI-1640 with Matrigel (1:10 dilution; BD Biosciences). The mice (license no. SCXK 2011-0029; Sun Yat-Sen University; $n=42$; age, 28-35 days; weight, 12-13 g) were randomly divided into 7 groups by the breeder. The mice were first divided into 3 main groups $\left(\mathrm{CD} 133^{+} \mathrm{CD} 44^{+}, \mathrm{CD} 133^{-} \mathrm{CD} 44^{-}\right.$and $\mathrm{NaCl}$ solution). The $\mathrm{CD} 133^{+} \mathrm{CD} 44^{+}$and $\mathrm{CD} 133{ }^{-} \mathrm{CD} 44^{-}$groups were further respectively divided into 3 subgroups $(2,000,20,000$ and 200,000 cells). Thus, there were 7 subgroups, with 6 mice in each group. Only the mice in the CD133 ${ }^{+} \mathrm{CD} 44^{+}$ main group formed tumors. Two hundred microliters of cell suspension $\left(2,000 / 20,000 / 200,000 \mathrm{CD} 33^{+} \mathrm{CD} 44^{+}\right.$or CD133-CD44- cells) or $\mathrm{NaCl}$ solution were then injected subcutaneously into the BALB/C-nu/nu mice. Tumor volumes and the body weight of the mice were measured at regular time intervals using an electronic balance. After 4 weeks, 
the mice were administered an intraperitoneal anesthesia with $4 \%$ chloral hydrate $(400 \mathrm{mg} / \mathrm{kg})$, and sacrificed by cervical dislocation and the tumors were removed. Following removal, the tumors were stored in formalin and were sent to Google Biological Technology Co., Ltd. (Wuhan, China) for processing (the tumors were fixed in $10 \%$ neutral buffered formalin, and then subjected to conventional methods of dehydration, paraffin-embedding and H\&E staining). All animal experiments were conducted in accordance with the protocol of the Institutional Animal Care and Use Committee of Sun Yat-Sen University (IACUC-DB-15-1210; Guangzhou, China). and following the approval of the Research Ethics Committee of Guangdong General Hospital, Guangdong Academy of Medical Sciences (no. GDREC 2015268A).

Transfection with small interfering RNA (siRNA) targeting Bmi-1 (Bmi-1-siRNA). The sequences of the siRNAs used to suppress Bmi-1 were as follows: forward, 5'-GCGGU AACCACCAAUCUUCdTdT-3' and reverse, 3'-dTd TCGCC AUUGGUGGUUAGAAG-5', which targeted the sequence of GCGGTAACCACCAATCTTC. The control siRNA sequence was custom ordered and provided by Shanghai SBO Medical Biotechnology Co., Ltd. (Shanghai, China). The CD133 ${ }^{+} \mathrm{CD} 44^{+}$ HCT116 cells were transfected with $100 \mathrm{nM}$ of siRNA using SunBio Trans-EZ (SBO) according instructions provided by the manufacturer. Cells only transfected with reagent (normal cells) were used as negative controls.

Reverse transcription-quantitative PCR (RT-qPCR). Total RNA was extracted from thye cultured cells using TRIzol reagent [Takara Biotechnology (Dalian) Co., Ltd., Dalian, China] and $1.0 \mu \mathrm{g}$ of total RNA was used for cDNA synthesis using the PrimeScript RT reagent Master mix (Takara Biotechnology (Dalian) Co., Ltd.). Quantitative (real-time) PCR (qPCR) was performed using SYBR Premix Ex Taq II (Tli RNaseH Plus) (Takara Biotechnology (Dalian) Co., Ltd.) with an ABI PRISM 7500 Fast Real-Time PCR system (Bio-Rad Laboratories, Inc., Hercules, CA, USA) with the following program: $95^{\circ} \mathrm{C}$ for $30 \mathrm{sec}, 95^{\circ} \mathrm{C}$ for $5 \mathrm{sec}, 60^{\circ} \mathrm{C}$ for $1 \mathrm{~min}$, and $95^{\circ} \mathrm{C}$ for $30 \mathrm{sec}$, for 40 cycles. The results were analyzed using the $2^{-\Delta \Delta \mathrm{CT}}$ method. $\beta$-actin gene expression was measured as an endogenous control. Experiments were carried out in technical triplicates and were repeated at least twice independently. Primers were custom ordered (Boshang Biotechnology Co., Ltd, Shanghai, China) with the following sequences: $B m i-1$ forward, 5'-TCTGGGAGTGACAAGG-3' and reverse, 5'-AAACAAG AAGAGGTGGA-3'; E-cadherin forward, 5'-TGCCCAGAA AATGAAAAAGG-3' and reverse, 5'-GTGTATGTGGCAAT GCGTTC-3'; $\beta$-actin forward, 5'-GCCAACACAGTGC TGTCTG-3' and reverse, 5'-TACTCCTGCTTGCTGATCCA-3'.

Western blot analysis. The cells were lysed in lysis buffer (50 mM Tris $\mathrm{pH} \mathrm{7.4,} 150 \mathrm{mM} \mathrm{NaCl,} \mathrm{0.1 \%} \mathrm{NP-40,} \mathrm{0.5 \%} \mathrm{sodium}$ deoxycholate). The protein concentration of the lysate was quantitated using the BSA method. Equal amounts of lysate were loaded and separated by SDS-polyacrylamide gels, and transferred onto nitrocellulose membranes (Bio-Rad Laboratories, Inc.). The membranes were blocked with $5 \%$ non-fat milk powder in TBS for $1 \mathrm{~h}$ and probed with primary antibodies against Bmi-1 (D20B7) rabbit monoclonal antibody (mAb) (\#6964,
1:1,000 dilution) and E-cadherin (4A2) mouse mAb (\#14472, 1:1,000 dilution) (both from Cell Signalling Technology, Inc., Danvers, MA, USA), and GAPDH (KC-5G4, 1:8,000 dilution; Kangchen Biotech, Inc., Shanghai, China). After washing with TBS-T, the membranes were incubated with secondary antibodies (1:6,000 dilution, A21020, HRP goat anti-rabbit; A21010, HRP goat anti-mouse; Abbkine, Redlands, CA, USA) and visualized using chemiluminescence with ImageQuant LAS 500 software (GE Healthcare Life Sciences, Buckinghamshire, UK).

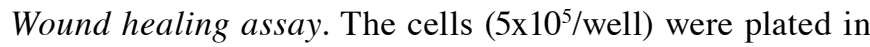
6 -well plates and cultured until they reached confluence. A diametric scratch was created using a pipette tip and washed with PBS 3 times. The cells were photographed under a microscope (Leica DMI1, Leica Microsystems Inc.) in several pre-marked spots as $0 \mathrm{~h}$. Images were then acquired at $24 \mathrm{~h}$ in the same spots for comparison. The scratch width was measured and the migration rates of each group cells were compared on average using Image-Pro Plus 6.0 software (Media Cybernetics, Inc., Rockville, MD, USA).

Transwellmigration assay. A Matrigel matrix (BD Biosciences) was used at a working concentration of $300 \mu \mathrm{g} / \mathrm{ml}$; the cells were plated in 24-well plates at $100 \mu \mathrm{l} /$ well and cultured in an incubator for $1 \mathrm{~h}$ before the Falcon cell culture inserts (Corning, Inc.) were added. The cells were resuspended in RPMI-1640 at a concentration of $1 \times 10^{5} / \mathrm{ml}$. The upper chamber was loaded with $100 \mu \mathrm{l}$ of cell suspension and the lower chamber was loaded with $500 \mu \mathrm{l}$ of RPMI-1640 with $20 \%$ FBS. Following incubation for $24 \mathrm{~h}$ at $37^{\circ} \mathrm{C}$ with $5 \% \mathrm{CO}_{2}$, the filter was fixed with methanol and stained with $10 \%$ Giemsa. The cells on the upper side of the filter were wiped off using a cotton swab. The cells that had migrated to the undersurface of the membrane were counted under a microscope (Leica DMI1, Leica Microsystems Inc.). Nine microscopic fields (x100 magnification) were randomly selected to count the cells. Each assay was carried out in triplicate.

Statistical analyses. All data are presented as the means \pm standard error of the mean (SEM). Statistical significance of differences between mean values was assessed by the Student's t-test for unpaired data. Comparisons of data between multiple groups were performed using analysis of variance (ANOVA). $A$ value of $\mathrm{P}<0.05$ was considered to indicate a statistically significant differene.

\section{Results}

Enrichment and screening of CCSCs by the use of SFM and MACS. The surface markers, CD133 and CD44, have been widely used for the selection and isolation of CCSCs from colon cancer cells (11-13). In our study, the CD133 ${ }^{+}$CD $44^{+}$ subpopulation of HCT116 cells before the experiment only accounted for $<1.00 \%$; thus, these cells were defined as CD133-CD44- cells. Following culture in SFM and subsequent MACS, we found that the proportion of $\mathrm{CD} 133^{+} \mathrm{CD} 44^{+}$cells greatly increased and these cells were defined as CCSCs (Fig. 1). Furthermore, it seemed that the proportion of $\mathrm{CD} 133^{+} \mathrm{CD} 44^{+}$cells depended on the amount of $\mathrm{CD} 133^{+}$cells. In addition, there was no significant difference in the frequency 

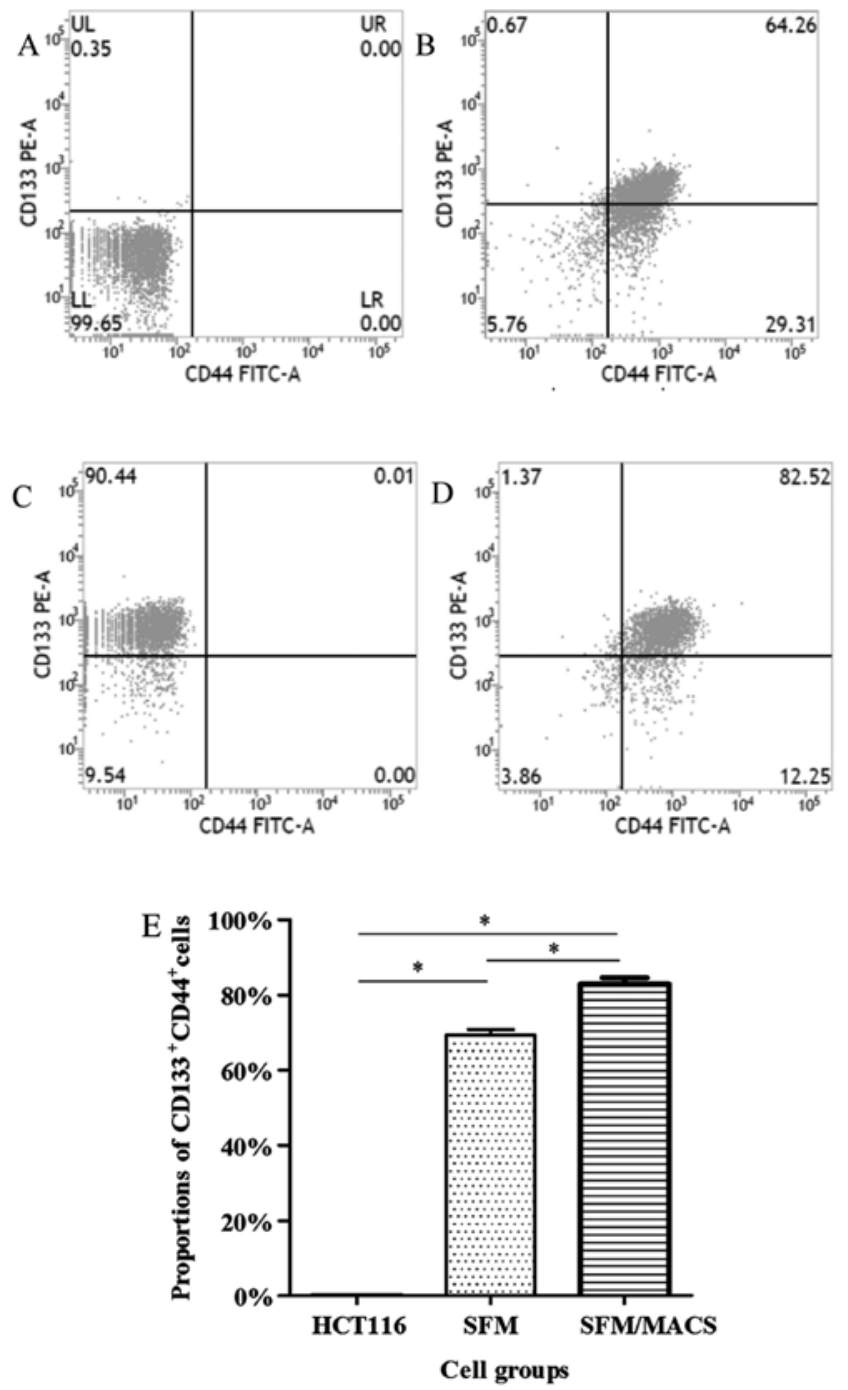

Figure 1. Proportions of $\mathrm{CD} 133^{+} \mathrm{CD} 44^{+}$cells as analyzed by flow cytometry. (A) The proportion of $\mathrm{CD} 133^{+} \mathrm{CD} 44^{+}$cells was originally $<1.00 \%$ in the HCT116 cells. (B) This increased to $69.27 \pm 1.56 \%$ following culture in sphere formation medium (SFM); (C) This increased even further to $90.40 \pm 0.85 \%$ (for $\mathrm{CD} 133^{+}$cells) with magnetic-activated cell sorting (MACS); and (D) to $82.91 \pm 1.60 \%$ with MACS. (E) Quantitative analysis of the results. The difference between the3 groups (HCT116 cells before culture with SFM and MACS, cells cultured in SFM, and cells after MACS) was significant, ${ }^{*} \mathrm{P}<0.05$.

of the $\mathrm{CD}_{133^{+}}$and $\mathrm{CD} 44^{+}$subpopulation between the CCSCs transfected with the control siRNA or these transfected with Bmi-1-siRNA (data not shown).

Colony-forming ability of CCSCs in vitro. Colony formation assay in vitro was used to identify the CSCs, which reflected the self-renewal and differentiation abilities of the CSCs. Six-well plates seeded with cells were photographed following culture for 1 week and the cloning efficiency of the $\mathrm{CD} 133^{+} \mathrm{CD} 44^{+}$cells was markeldy higher than that of the CD133-CD44- cells (Fig. 2). The biggest and smallest colonies were almost 10.0 and $5.00 \mu \mathrm{m}$ in diameter as observed under a microscope (x100 magnification) after being stained with $10 \%$ Giemsa.

Proliferative ability and viability of CCSCs in vitro. Cell proliferative ability and cell viability assays were performed using CCK-8 assay as previously described (30-34). The distinction
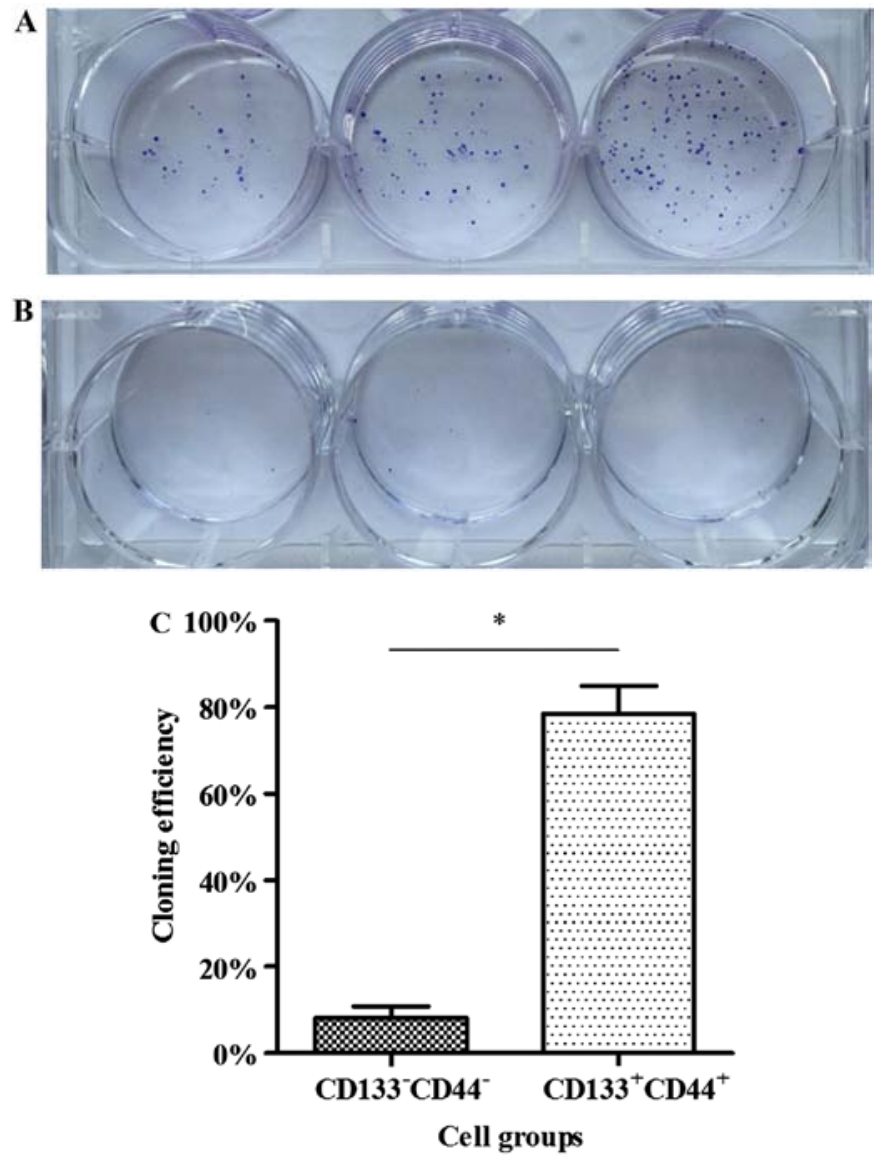

Figure 2. Colonies of cells following staining with $10 \%$ Giemsa by the naked eye and a microscope. (A) Cloning efficiency of $\mathrm{CD} 133^{+} \mathrm{CD} 44^{+}$cells was $78.44 \pm 6.54 \%$ on average; (B) cloning efficiency of CD133 ${ }^{-}{ }^{-} 44^{-}$cells was $8.22 \pm 2.68 \%$ on average. (C) Quantitative analysis of the results. The difference between the 2 groups was significant, ${ }^{*} \mathrm{P}<0.05$.

between the 2 groups of cells was most conspicuously reflected with 8,000 cells after different gradients of cell populations were designed according to the manufacturer's instructions (Fig. 3A). Subsequently, another 8,000 cells from each group were cultured as above to compare cell viability, and the assay was repeated 30 times. The $\mathrm{CD} 133^{+} \mathrm{CD} 44^{+}$cells exhibited a greater viability compared with the CD133-CD44- cells (Fig. 3B).

Tumor transplantation assay using BALB/c-nu/nu mice in vivo. We used a tumor transplantation assay to confirm that the CCSCs had a stronger tumorigenicity in vivo, which is also considered to be an important characteristic of CSCs. At 4 weeks after the injection, the BALB/c-nu/nu mice were sacrificed and the tumors were removed. The body weights of the mice injected with the $\mathrm{CD} 133^{+} \mathrm{CD} 44^{+}$cells were markedly lower than those of the mice injected with the CD133-CD44cells or with $\mathrm{NaCl}$ (Fig. 4A). Only the mice injected with the $\mathrm{CD} 133^{+} \mathrm{CD} 44^{+}$cells developed tumors (100\%), which were concentration-dependent (Fig. 4B). The shortest tumor formation time was approximately 10 days with the injection of 200,000 cells and the tumor growth curves in the mice in the $\mathrm{CD} 133^{+} \mathrm{CD} 44^{+}$-injected group are shown in Fig. 4C. All tumors underwent routine pathological section examinations to confirm that the assay was successful (Fig. 4D). 

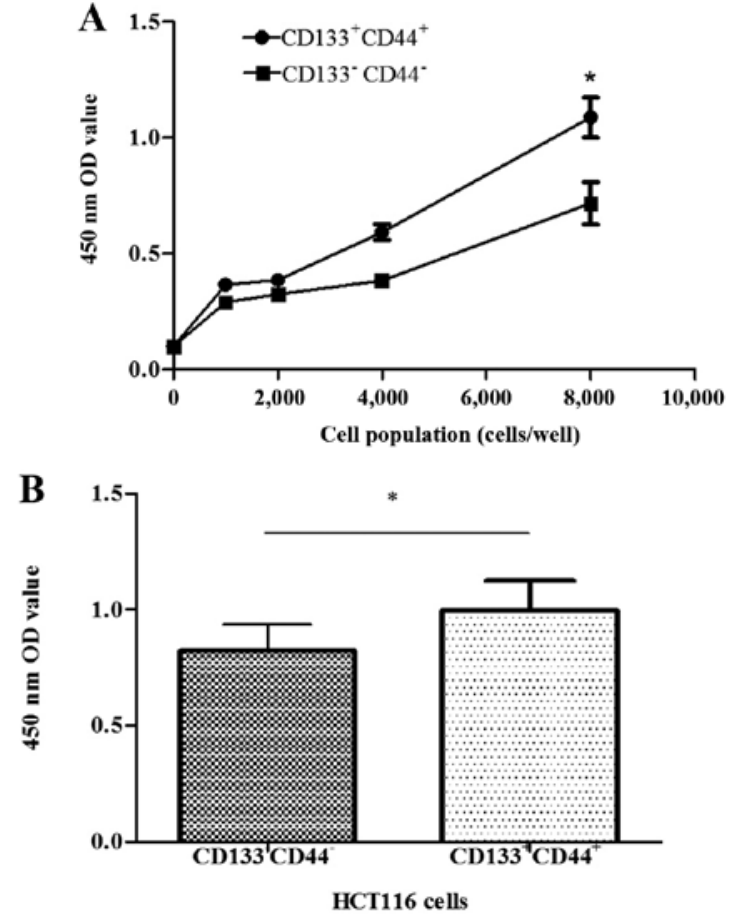

Figure 3. Cell proliferation curves and comparison of the viability of

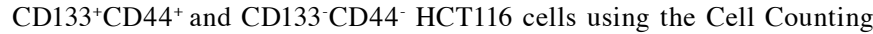
Kit-8 (CCK-8). (A) The distinction was most conspicuously reflected with 8,000 cells in each group: $1.09 \pm 0.09$ and $0.72 \pm 0.09$; (B) Values of 8,000 cells in each group: $1.00 \pm 0.13$ and $0.82 \pm 0.11$, repeated 30 times. ${ }^{*} \mathrm{P}<0.05$.

CCSCs exhibit decreased invasive and migratory abilities after the silencing of Bmi-1. The oncogene Bmi-1 plays a critical role in the maintenance of CSCs (25) and we found that it was expressed in the HCT116 colon cancer cell line. Therefore, we investigated whether Bmi-1 affects the metastatic potential of CCSCs by gene silencing, using siRNA transfection and then confirmed our findings by RT-qPCR and western blot analysis (Fig. 5). By performing wound healing and Transwell migration assays, we found that the CCSCs exhibited decreased invasive and migratory abilities, which are often representative of metastatic potential, after the silencing of Bmi-1 (Figs. 6 and 7).

We further explored the possible mechanisms responsible for the effects Bmi-1 on CCSCs. Since EMT occurs during cancer metastasis and interacts with CSCs $(17,18)$, we focused on E-cadherin (a hallmark of EMT; the loss of E-cadherin is indicative of EMT) as a target protein. We found that Bmi-1 had a negative impact on E-cadherin. In the cells not transfected with Bmi-1-siRNA, the expression of E-cadherin was low. However, after the silencing of Bmi-1, E-cadherin expression markedly increased, as shown by RT-qPCR and western blot analysis (Fig. 5), which may indicate that Bmi-1 promotes the invasion and migration of CCSCs through the downregulation of E-cadherin, possibly by inducing EMT. The silencing of Bmi-1 increases E-cadhein expression, thus inhibiting EMT.

\section{Discussion}

The morbidity associated with colorectal cancer is ranked 3rd among malignant tumors in recent years on the basis of
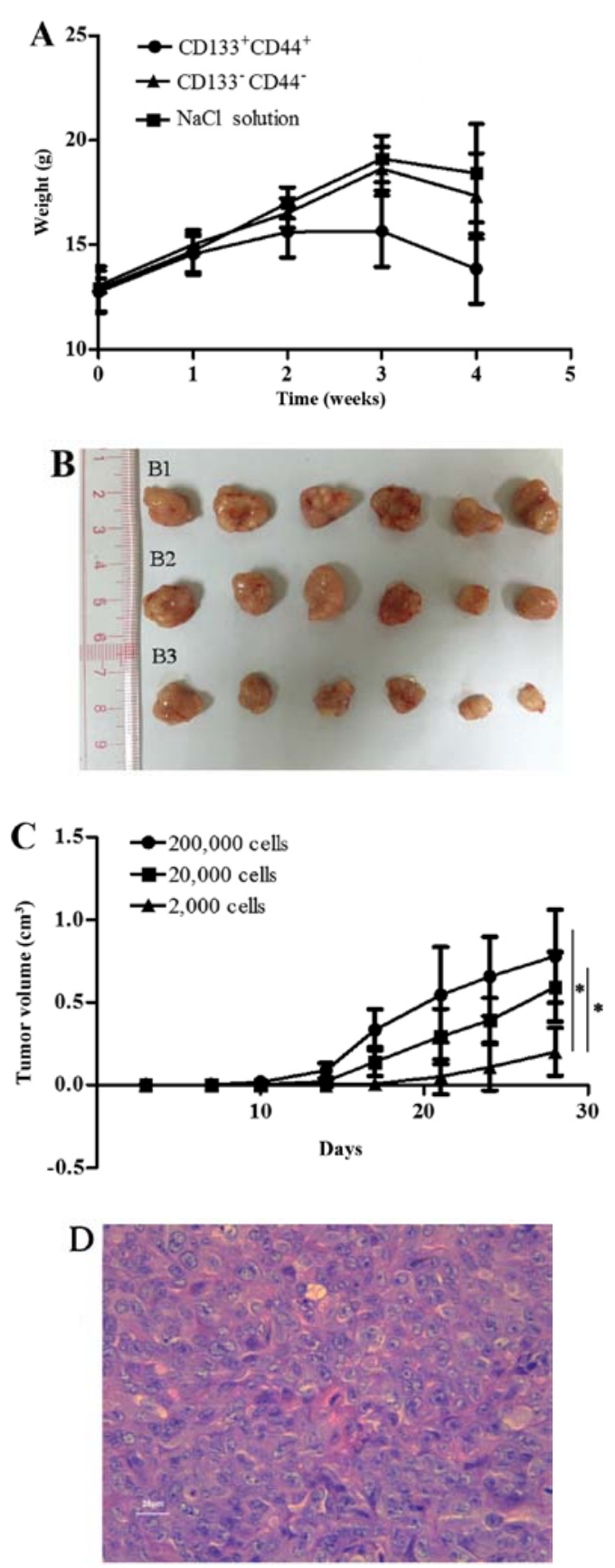

Figure 4. Tumor transplantation assay using BALB/c-nu/nu mice. (A) The body weights of the mice injected with $\mathrm{NaCl}$, or the $\mathrm{CD} 133^{-} \mathrm{CD} 44^{-}$cells or $\mathrm{CD} 133^{+} \mathrm{CD} 44^{+}$cells were measured over a period of 4 weeks. (B) Tumors of the mice in the $\mathrm{CD} 133^{+} \mathrm{CD} 44^{+}$group injected with various concentrations of the cells (B1, 200,000 cells; B2, 20,000 cells; B3, 2,000 cells) were measured using a ruler $(\mathrm{cm})$. (C) Tumor growth curves of the mice injected with various concentrations of $\mathrm{CD} 133^{+} \mathrm{CD} 44^{+}$cells $(200,000,20,000$ or 2,000 cells); ${ }^{*} \mathrm{P}<0.05$. (D) Pathological section examination stained with hematoxylin and eosin (H\&E) under a microscope (x400 magnification).

the treatment guidelines of early colorectal cancer in China published in 2015 (3). The prognosis of patients with colorectal cancer is closely related to early diagnosis and the 5-year survival rate decreases to $<12 \%$ at the advanced stage of the disease $(2,3)$. The incidence and metastasis associated with colorectal cancer are major concerns and obstacles to effective treatment in both Western and Eastern countries. It is thus crucial that further research be carried out to identify methods 

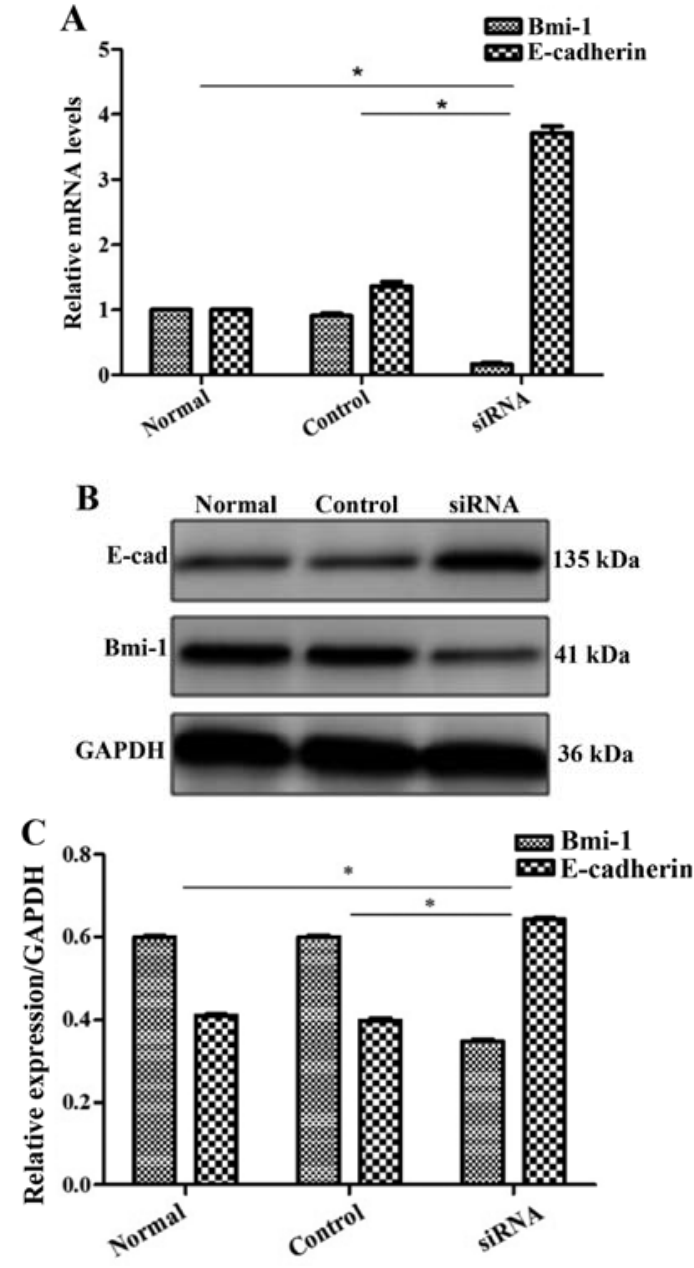

Figure 5. Expression of Bmi-1 and E-cadherin following transfection of colon cancer stem cells (CCSCs) with Bmi-siRNA. (A) RT-qPCR evaluation; (B and $\mathrm{C}$ ) western blot analysis and evaluation. ${ }^{*} \mathrm{P}<0.05$ compared to the control siRNA-transfected cells.

with which to prevent the development and metastasis of colon cancer.

The isolation and acquisition of CSCs is a major achievement in basic and clinical medicine. SFM and MACS can be used for the enrichment and selection of CSCs. Functional experiments in vitro and in vivo are often performed for the identification of CSCs (35-37). In this study, we found that the $\mathrm{CD} 133^{+} \mathrm{CD} 44^{+} \mathrm{HCT} 116$ cells had a greater cloning efficiency, an enhanced proliferative ability and increased viability, as well as a stronger tumorigenicity; therefore, they were used as CCSCs for subsequent experiments. The successful separation and identification of CCSCs in ours and other studies strongly supports the CSC theory in colon cancer.

CD133 and CD44 were discovered as important surface markers of CCSCs (11-13). It is recommended that the screening and identification of CSCs be performed with more than one marker. Different markers of cells may represent different functions and may prove helpful to the understanding of the overall features. For instance, CD133 may be associated with cloning efficiency and proliferative ability, while CD44 may be related to metastasis and survival prediction (16). It has been reported that other markers of CCSCs include membrane proteins, such as EpCAM (39), Lgr5 (40-42), CD24 (43),
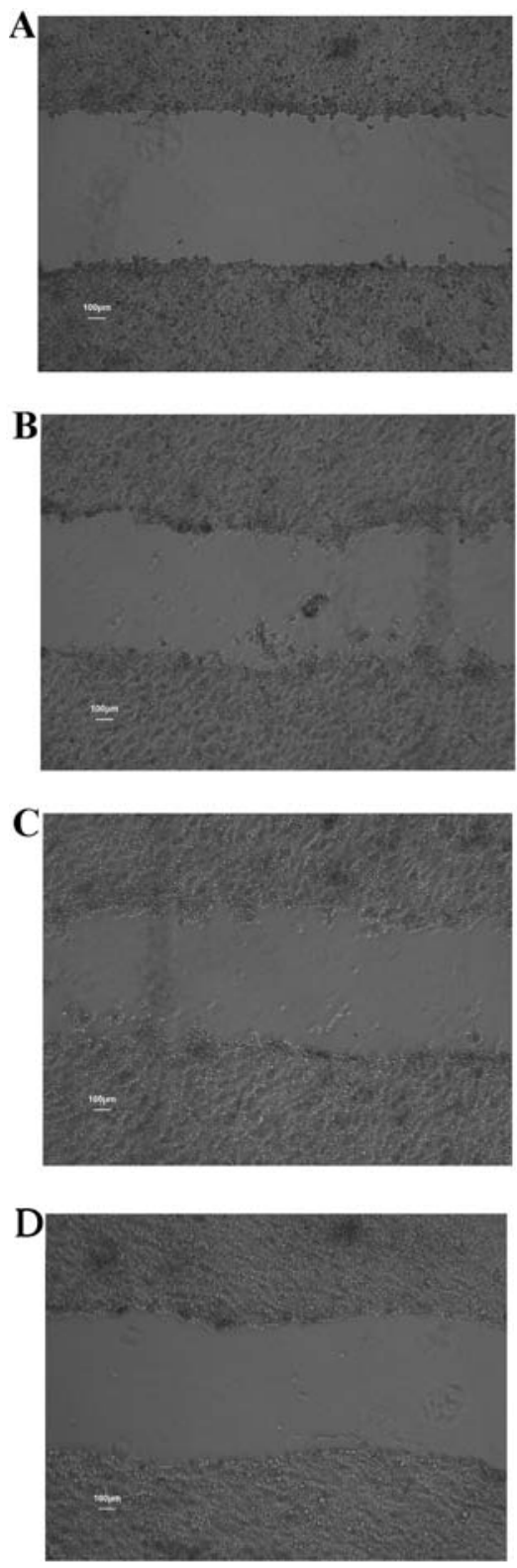

Figure 6. Wound healing ability of colon cancer stem cells (CCSCs) seeded in 6-well plates and cultured for $24 \mathrm{~h}$. (A) A diametric scratch using a pipette tip was made at $0 \mathrm{~h}$; (B) CCSCs treated with transfection reagent after $24 \mathrm{~h}$; (C) CCSCs transfected with control small interfering RNA (siRNA) and transfection reagent after $24 \mathrm{~h}$; (D) CCSCs transfected with Bmi-1-siRNA and transfection reagent after $24 \mathrm{~h} ; 24 \mathrm{~h}$ average migration rates of (B-D) were: $5.25 \pm 0.70,5.14 \pm 0.54$ and $3.93 \pm 0.38 \mu \mathrm{m} / \mathrm{h}$, respectively (shown in Fig. 7D).

CD26 (44,45), CD29 (46) and CD166 (38,47); cytosolic enzymes, such as ALDH1 $(48,49)$; transcription factors, such as as Oct4 (50), Sox2 (51), Ascl2 (52-54) and Hes1 (55,56); and even the Wnt (57) and Notch (55) signaling pathways. Different markers may reflect different functions of CCSCs from diverse perspectives and provide more targets for study and therapy. However, the critical one and interconnections among them have not yet been clearly elaborated.

The discovery and eradication of CSCs hold promise in cancer therapy, as well as genes acting on CSCs and the regulatory mechanisms. The epigenetic regulator, Bmi-1, is considered to play essential roles in the self-renewal and propagation of normal cells and CSCs (25). We found that CCSCs exhibited 

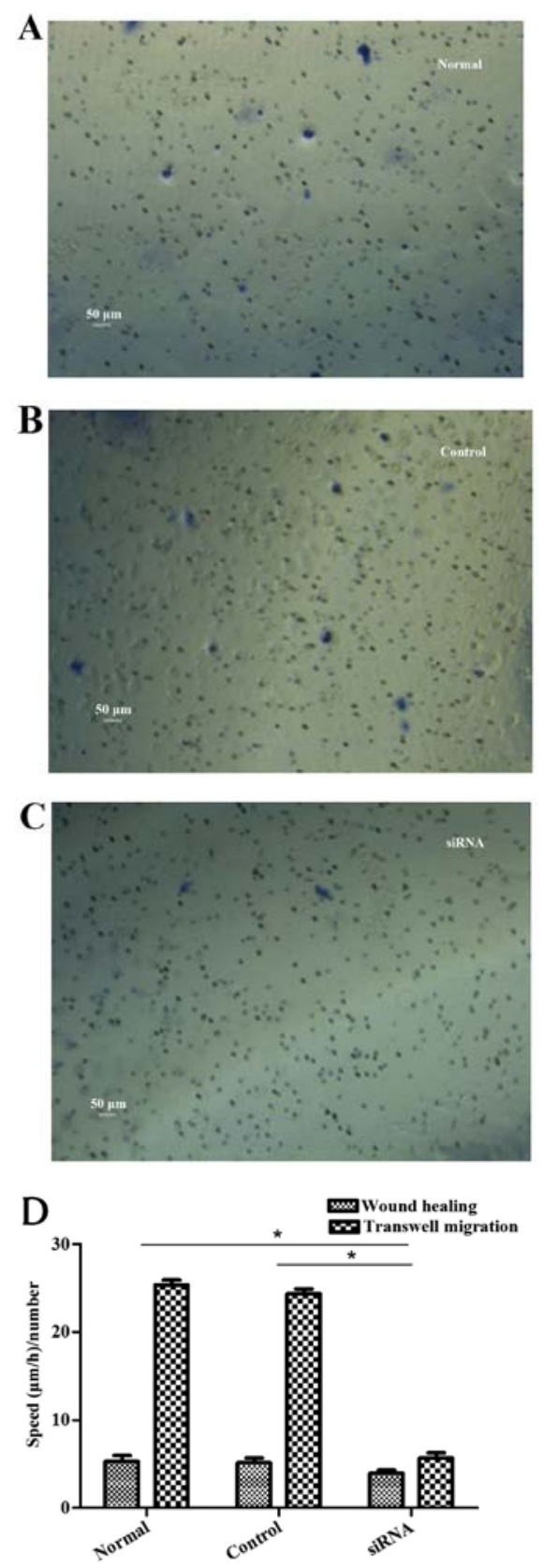

Figure 7. Cell numbers in the under surface of Transwell membrane after $24 \mathrm{~h}$ (A) Colon cancer stem cells (CCSCs) treated with transfection reagent after $24 \mathrm{~h}$; (B) CCSCs transfected with control small interfering RNA (siRNA) and transfection reagent after $24 \mathrm{~h}$; (C) CCSCs transfected with Bmi-1-siRNA and transfection reagent after $24 \mathrm{~h}$; (D) cell numbers in the undersurface of membrane of (A-C) were: $25.33 \pm 0.58,24.33 \pm 0.58$ and $5.67 \pm 0.58$ as observed under a microscope (x100 magnification) after staining with $10 \%$ Giemsa, respectively. ${ }^{*} \mathrm{P}<0.05$ compared to siRNA-transfected group.

a decreased invasive and migratory abilities after Bmi-1 was silenced by siRNA. This suggests that Bmi-1 is a positive regulator of cell invasion and migration in colon cancer and that the downregulation of Bmi-1 may help to prevent metastasis or the progression of colon cancer. Since the gene targeted therapy of cancer has important theoretical significance and clinical application prospects, the knockdown of Bmi-1 is expected to become supplementary treatment for colon cancer.

In addition, we found E-cadherin was upregulated when Bmi-1 was silenced, while vimentin and $\mathrm{N}$-cadherin were downregulated (although we could not make a statistical conclusion as they were weakly expressed in CCSCs originally; data not shown). This may indicate that Bmi-1 functions through the downregulation of E-cadhein, possibly by inducing EMT. This has been previously demonstrated in nasopharyngeal (58), breast $(59,60)$, melanoma (61), endometrial (62), prostate (63), and bladder (64) cancers. E-cadherin is a transmenbrane protein important for cell-cell junctions, it suppresses tumorigenesis and the metastasis of cancers, and its downregulation or loss is regarded as a hallmark of EMT. The downregulation or loss of E-cadherin on the surface leads to the shedding of many types of cancer cells from the tumor mass, which is the precondition of cancer invasion and metastasis $(65,66)$. The molecular mechanisms responsible for cancer metastasis, regarded as a promising target for cancer chemotherapy, are currently receiving increased attention. Bmi-1 was considered to play an important role in the pathogenesis of nasopharyngeal cancer by inducing EMT, partly by targeting the tumor suppressor, PTEN, thus activating the PI3K/Akt pathway (58). It was also demonstrated that Bmi-1 induced cell invasion with the activation of the Akt pathway in breast cancer cells (60). Alternatively, it was shown that Bmi-1 acted negatively on PTEN and E-cadherin in colorectal cancer from a histological perspective by Liao et al (67). Therefore, we speculate there is a strong possibility that Bmi-1 promotes the invasion and migration of CCSCs through the downregulation of E-cadherin and the induction of EMT, and through the PI3K/ Akt pathway. However, the crosstalk between different pathways for expanding the cellular communication signaling network should be also given several considerations. In this study, we put forward the hypothesis of the role of Bmi-1 and EMT in CCSCs for the first time, to the best of our knowledge. Namely, the eradication of CCSCs, and the blocking of EMT and the downregulation of Bmi-1 may together prevent the metastasis of colon cancer at an early stage and may thus improve the 5-year survival rate when applied clinically.

In conclusion, our study demonstrates that $\mathrm{CD} 133^{+} \mathrm{CD} 44^{+}$ HCT116 cells can be used as CCSCs for subsequent medical studies. Bmi-1 promotes the invasion and migration of CCSCs through the downregulation of E-cadherin, possibly by inducing EMT. This finding may provide a new target for colon cancer therapy. To this end, it would be of great interest for us to further investigate the signaling pathways and regulatory mechanisms of the interaction between Bmi-1 and EMT in colon cancer.

\section{Acknowledgements}

We sincerely thank other colleagues in our laboratory for their active help in this study. This study was supported by a grant from the Natural Science Foundation of Guangdong Province (2014A030313543).

\section{References}

1. Provenzale D, Jasperson K, Ahnen DJ, Aslanian H, Bray T, Cannon JA, David DS, Early DS, Erwin D, Ford JM, et al: Colorectal cancer screening, version 1.2015. J Natl Compr Canc Netw 13: 959-968, 2015.

2. Gastrointestinal surgery group, Colorectal and anal surgery group and Colorectal cancer Specialized Committee: Guidelines for diagnosis and comprehensive treatment of colorectal cancer liver metastases (V 2013). Zhonghua wei chang wai ke za zhi 16: 780-788, 2013 (In Chinese). 
3. Association of Digestive Endoscopy, Cancer endoscopy Specialized Committee: Guidelines for early colorectal cancer screening and endoscopic diagnosis and treatment in China (2014). Nat Med J China 95: 2235-2252, 2015 (In Chinese).

4. Polyak K and Hahn WC: Roots and stems: stem cells in cancer. Nat Med 12: 296-300, 2006.

5. Li F, Tiede B, Massagué J and Kang Y: Beyond tumorigenesis: cancer stem cells in metastasis. Cell Res 17: 3-14, 2007.

6. Kakarala M and Wicha MS: Implications of the cancer stem-cell hypothesis for breast cancer prevention and therapy. J Clin Oncol 26: 2813-2820, 2008.

7. Bonnet D and Dick JE: Human acute myeloid leukemia is organized as a hierarchy that originates from a primitive hematopoietic cell. Nat Med 3: 730-737, 1997.

8. Singh SK, Clarke ID, Terasaki M, Bonn VE, Hawkins C, Squire J and Dirks PB: Identification of a cancer stem cell in human brain tumors. Cancer Res 63: 5821-5828, 2003.

9. Ponti D, Costa A, Zaffaroni N, Pratesi G, Petrangolini G, Coradini D, Pilotti S, Pierotti MA and Daidone MG: Isolation and in vitro propagation of tumorigenic breast cancer cells with stem/progenitor cell properties. Cancer Res 65: 5506-5511, 2005.

10. Li C, Heidt DG, Dalerba P, Burant CF, Zhang L, Adsay V, Wicha M, Clarke MF and Simeone DM: Identification of pancreatic cancer stem cells. Cancer Res 67: 1030-1037, 2007.

11. O'Brien CA, Pollett A, Gallinger S and Dick JE: A human colon cancer cell capable of initiating tumour growth in immunodeficient mice. Nature 445: 106-110, 2007.

12. Ricci-Vitiani L, Lombardi DG, Pilozzi E, Biffoni M, Todaro M Peschle C and De Maria R: Identification and expansion of human colon-cancer-initiating cells. Nature 445: 111-115, 2007.

13. Chu P, Clanton DJ, Snipas TS, Lee J, Mitchell E, Nguyen ML, Hare E and Peach RJ: Characterization of a subpopulation of colon cancer cells with stem cell-like properties. Int J Cancer 124: $1312-1321,2009$

14. Laganà AS, Colonese F, Colonese E, Sofo V, Salmeri FM, Granese R, Chiofalo B, Ciancimino L and Triolo O: Cytogenetic analysis of epithelial ovarian cancer's stem cells: an overview on new diagnostic and therapeutic perspectives. Eur J Gynaecol Oncol 36: 495-505, 2015

15. López J, Valdez-Morales FJ, Benítez-Bribiesca L, Cerbón M and Carrancá AG: Normal and cancer stem cells of the human female reproductive system. Reprod Biol Endocrinol 11: 53, 2013.

16. Jing F, Kim HJ, Kim CH, Kim YJ, Lee JH and Kim HR: Colon cancer stem cell markers CD44 and CD133 in patients with colorectal cancer and synchronous hepatic metastases. Int J Oncol 46: 1582-1588, 2015

17. Yilmaz M and Christofori G: EMT, the cytoskeleton, and cancer cell invasion. Cancer Metastasis Rev 28: 15-33, 2009.

18. Birchmeier W and Birchmeier C: Epithelial-mesenchymal transitions in development and tumor progression. EXS 74 $1-15,1995$

19. Onder TT, Gupta PB, Mani SA, Yang J, Lander ES and Weinberg RA: Loss of E-cadherin promotes metastasis via multiple downstream transcriptional pathways. Cancer Res 68: 3645-3654, 2008.

20. Jacobs JJ and van Lohuizen M: Polycomb repression: from cellular memory to cellular proliferation and cancer. Biochim Biophys Acta 1602: 151-161, 2002

21. Piunti A and Pasini D: Epigenetic factors in cancer development: polycomb group proteins. Future Oncol 7: 57-75, 2011

22. Honig A, Weidler C, Häusler S, Krockenberger M, Buchholz S, Köster F, Segerer SE, Dietl J and Engel JB: Overexpression of polycomb protein BMI-1 in human specimens of breast, ovarian, endometrial and cervical cancer. Anticancer Res 30: 1559-1664, 2010.

23. Vékony H, Raaphorst FM, Otte AP, van Lohuizen M,Leemans CR, van der Waal I snf Bloemena E: High expression of Polycomb group protein EZH2 predicts poor survival in salivary gland adenoid cystic carcinoma. J Clin Pathol 61: 744-749, 2008

24. Silva J, García JM, Peña C, García V, Domínguez G, Suárez D, Camacho FI, Espinosa R, Provencio M, España P and Bonilla $F$ : Implication of polycomb members Bmi-1, Mel-18, and $\mathrm{Hpc}-2$ in the regulation of p16INK4a, p14ARF, h-TERT, and c-Myc expression in primary breast carcinomas. Clin Cancer Res 12 : 6929-6936, 2006.

25. Molofsky AV, Pardal R, Iwashita T, Park IK, Clarke MF and Morrison SJ: Bmi-1 dependence distinguishes neural stem cell self-renewal from progenitor proliferation. Nature 425: 962-967, 2003
26. Hu XH, Sha WH, Lin F, Cen RY and Liao SY: The correlation between genetic expressions of Bmi-1 and clinicopathological parameters of colorectal cancer. Modern Digestion \& Intervention 16: 1-5, 2011 (In Chinese).

27. Yang J, Liu J, Lyu X and Fei S: Resveratrol inhibits cell proliferation and up-regulates MICA/B expression in human colon cancer stem cells. Xi Bao Yu Fen Zi Mian Yi Xue Za Zhi 31: 889-893, 2015 (In Chinese).

28. Xiong B, Ma L, Hu X, Zhang $\mathrm{C}$ and Cheng Y: Characterization of side population cells isolated from the colon cancer cell line SW480. Int J Oncol 45: 1175-1183, 2014.

29. Feng Y, Dai X, Li X, Wang H, Liu J, Zhang J, Du Y and Xia L: EGF signalling pathway regulates colon cancer stem cell proliferation and apoptosis. Cell Prolif 45: 413-419, 2012.

30. Zhou M, Lu Y, Yuan L, Zheng L, Liu Y, Hong M, Zhang C and Li X: Preliminary screening of downstream proteins of Sox 2 and role of Sox 2 in colonic cancer cell migration and invasion. Nan Nan Fang Yi Ke Da Xue Xue Bao 34: 1594-1600, 2014 (In Chinese)

31. Zhang M, Cui F, Lu S, Lu H, Xue Y, Wang J, Chen J, Zhao S, Ma S, Zhang Y, et al: Developmental pluripotency-associated 4: a novel predictor for prognosis and a potential therapeutic target for colon cancer. J Exp Clin Cancer Res 34: 60, 2015.

32. Xie X, Zhao Y, Ma CY, Xu XM, Zhang YQ, Wang CG, Jin J, Shen X, Gao JL, Li N, et al: Dimethyl fumarate induces necroptosis in colon cancer cells through GSH depletion/ROS increase/MAPKs activation pathway. Br J Pharmacol 172: 3929-3943, 2015

33. Lin YU, Wu T, Yao Q, Zi S, Cui L, Yang M and Li J: LGR5 promotes the proliferation of colorectal cancer cells via the Wnt/ $\beta$-catenin signaling pathway. Oncol Lett 9: 2859-2863, 2015.

34. Peng HX, Wu WQ, Yang DM, Jing R, Li J, Zhou FL, Jin YF, Wang SY and Chu YM: Role of B7-H4 siRNA in proliferation, migration, and invasion of LOVO colorectal carcinoma cell line. BioMed Res Int 2015: 326981, 2015.

35. Zeng L, Qiu L, Yang XT, Zhou YH, Du J, Wang HY, Sun JH, Yang $\mathrm{C}$ and Jiang JX: Isolation of lung multipotent stem cells using a novel microfluidic magnetic activated cell sorting system. Cell Biol Int 39: 1348-1353, 2015.

36. Xue ZX, Zheng JH, Zheng ZQ, Cai JL, Ye XH, Wang C, Sun WJ, Zhou X, Lu MD, Li PH and Cai ZZ: Latexin inhibits the proliferation of $\mathrm{CD}_{133^{+}}$miapaca-2 pancreatic cancer stem-like cells. World J Surg Oncol 12: 1-11, 2014

37. Zhang DG, Jiang AG, Lu HY, Zhang LX and Gao XY: Isolation, cultivation and identification of human lung adenocarcinoma stem cells. Oncol Lett 9: 47-54, 2015.

38. Levin TG, Powell AE, Davies PS, Silk AD, Dismuke AD, Anderson EC, Swain JR and Wong MH: Characterization of the intestinal cancer stem cell marker CD166 in the human and mouse gastrointestinal tract. Gastroenterology 139: 2072-2082, 2010.

39. Dalerba P, Dylla SJ, Park IK, Liu R, Wang X, Cho RW, Hoey T, Gurney A, Huang EH, Simeone DM, et al: Phenotypic characterization of human colorectal cancer stem cells. Proc Natl Acad Sci USA 104: 10158-10163, 2007.

40. Femia AP, Dolara P, Salvadori M and Caderni G: Expression of LGR-5, MSI-1 and DCAMKL-1, putative stem cell markers, in the early phases of 1,2-dimethylhydrazine-induced rat colon carcinogenesis: correlation with nuclear $\beta$-catenin. BMC Cancer 13: 48, 2013.

41. Yui S, Nakamura T, Sato T, Nemoto Y, Mizutani T, Zheng X, Ichinose S, Nagaishi T, Okamoto R, Tsuchiya K, et al: Functional engraftment of colon epithelium expanded in vitro from a single adult Lgr5 ${ }^{+}$stem cell. Nat Med 18: 618-623, 2012.

42. Barker N, van Es JH, Kuipers J, Kujala P, van den Born M, Cozijnsen M, Haegebarth A, Korving J, Begthel H, Peters PJ and Clevers H: Identification of stem cells in small intestine and colon by marker gene Lgr5. Nature 449: 1003-1007, 2007.

43. Vermeulen L, Todaro M, de Sousa Mello F, Sprick MR, Kemper K, Perez Alea M, Richel DJ, Stassi G and Medema JP: Single-cell cloning of colon cancer stem cells reveals a multi-lineage differentiation capacity. Proc Natl Acad Sci USA 105: 13427-13432, 2008.

44. Fric P, Sovová V, Sloncová E, Lojda Z, Jirásek A and Cermák J: Different expression of some molecular markers in sporadic cancer of the left and right colon. Eur J Cancer Prev 9: 265-268, 2000

45. Pang R, Law WL, Chu AC, Poon JT, Lam CS, Chow AK, Ng L, Cheung LW, Lan XR, Lan HY, et al: A subpopulation of $\mathrm{CD}^{2} 6^{+}$ cancer stem cells with metastatic capacity in human colorectal cancer. Cell Stem Cell 6: 603-615, 2010 . 
46. Fujimoto K, Beauchamp RD and Whitehead RH: Identification and isolation of candidate human colonic clonogenic cells based on cell surface integrin expression. Gastroenterology 123: 1941-1948, 2002.

47. Lugli A, Iezzi G, Hostettler I, Muraro MG, Mele V, Tornillo L, Carafa V, Spagnoli G, Terracciano L and Zlobec I: Prognostic impact of the expression of putative cancer stem cell markers CD133, CD166, CD44s, EpCAM, and ALDH1 in colorectal cancer. Br J Cancer 103: 382-390, 2010.

48. Huang EH, Hynes MJ, Zhang T, Ginestier C, Dontu G, Appelman H, Fields JZ, Wicha MS and Boman BM: Aldehyde dehydrogenase 1 is a marker for normal and malignant human colonic stem cells (SC) and tracks SC overpopulation during colon tumorigenesis. Cancer Res 69: 3382-3389, 2009.

49. Dylla SJ, Beviglia L, Park IK, Chartier C, Raval J, Ngan L, Pickell K, Aguilar J, Lazetic S, Smith-Berdan S, et al: Colorectal cancer stem cells are enriched in xenogeneic tumors following chemotherapy. PLoS One 3: e2428, 2008.

50. Park IH, Zhao R, West JA, Yabuuchi A, Huo H, Ince TA, Lerou PH, Lensch MW and Daley GQ: Reprogramming of human somatic cells to pluripotency with defined factors. Nature 451: 141-146, 2008.

51. Saigusa S, Tanaka K, Toiyama Y, Yokoe T, Okugawa Y, Ioue Y, Miki C and Kusunoki M: Correlation of CD133, OCT4, and SOX2 in rectal cancer and their association with distant recurrence after chemoradiotherapy. Ann Surg Oncol 16: 3488-3498, 2009.

52. Ziskin JL, Dunlap D, Yaylaoglu M, Fodor IK, Forrest WF Patel R, Ge N, Hutchins GG, Pine JK, Quirke P, et al: In situ validation of an intestinal stem cell signature in colorectal cancer. Gut 62: 1012-1023, 2013.

53. Zhu R, Yang Y, Tian Y, Bai J, Zhang X, Li X, Peng Z, He Y, Chen L, Pan Q, et al: Ascl2 knockdown results in tumor growth arrest by miRNA-302b-related inhibition of colon cancer progenitor cells. PLoS One 7: e32170, 2012.

54. Jubb AM, Chalasani S, Frantz GD, Smits R, Grabsch HI, Kavi V, Maughan NJ, Hillan KJ, Quirke P and Koeppen H: Achaete-scute like $2(\operatorname{ascl} 2)$ is a target of Wnt signalling and is upregulated in intestinal neoplasia. Oncogene 25: 3445-3457, 2006.

55. Reedijk M, Odorcic S, Zhang H, Chetty R, Tennert C, Dickson BC, Lockwood G, Gallinger S and Egan SE: Activation of Notch signaling in human colon adenocarcinoma. Int J Oncol 33: 1223-1229, 2008.

56. Gao F, Zhang Y, Wang S, Liu Y, Zheng L, Yang J, Huang W, Ye Y, Luo W and Xiao D: Hes1 is involved in the self-renewal and tumourigenicity of stem-like cancer cells in colon cancer Sci Rep 4: 3963, 2014.
57. Vermeulen L, De Sousa E Melo F, van der Heijden M, Cameron K, de Jong JH, Borovski T, Tuynman JB, Todaro M, Merz $\mathrm{C}$, Rodermond $\mathrm{H}$, et al: Wnt activity defines colon cancer stem cells and is regulated by the microenvironment. Nat Cell Biol 12: 468-476, 2010.

58. Song LB, Li J, Liao WT, Feng Y, Yu CP, Hu LJ, Kong QL, $\mathrm{Xu}$ LH, Zhang X, Liu WL, et al: The polycomb group protein Bmi-1 represses the tumor suppressor PTEN and induces epithelial-mesenchymal transition in human nasopharyngeal epithelial cells. J Clin Invest 119: 3626-3636, 2009.

59. Li H, Song F, Chen X, Li Y, Fan J and Wu X: Bmi-1 regulates epithelial-to-mesenchymal transition to promote migration and invasion of breast cancer cells. Int J Clin Exp Pathol 7: 3057-3064, 2014

60. Guo BH, Feng Y, Zhang R, Xu LH, Li MZ, Kung HF, Song LB and Zeng MS: Bmi-1 promotes invasion and metastasis, and its elevated expression is correlated with an advanced stage of breast cancer. Mol Cancer 10: 10, 2011.

61. Liu S, Tetzlaff MT, Cui R and Xu X: miR-200c inhibits melanoma progression and drug resistance through down-regulation of BMI-1. Am J Pathol 181: 1823-1835, 2012.

62. Dong P, Kaneuchi M, Watari H, Hamada J, Sudo S, Ju J and Sakuragi N: MicroRNA-194 inhibits epithelial to mesenchymal transition of endometrial cancer cells by targeting oncogene BMI-1. Mol Cancer 10: 99, 2011

63. Nanta R, Kumar D, Meeker D, Rodova M, Van Veldhuizen PJ, Shankar S and Srivastava RK: NVP-LDE-225 (Erismodegib) inhibits epithelial-mesenchymal transition and human prostate cancer stem cell growth in NOD/SCID IL2R $\gamma$ null mice by regulating Bmi-1 and microRNA-128. Oncogenesis 2: e42, 2013.

64. Liu L, Qiu M, Tan G, Liang Z, Qin Y, Chen L, Chen H and Liu J: miR-200c inhibits invasion, migration and proliferation of bladder cancer cells through down-regulation of BMI-1 and E2F3. J Transl Med 12: 305, 2014

65. Dass SD, Cheah PL, Ong DB, Teoh KH and Looi LM: E-cadherin downregulation at the infiltrating tumour front is associated with histological grade and stage in colorectal carcinoma of Malaysians. Malays J Pathol 37: 19-24, 2015.

66. Le Bras GF, Taubenslag KJ and Andl CD: The regulation of cell-cell adhesion during epithelial-mesenchymal transition, motility and tumor progression. Cell Adh Migr 6: 365-373, 2012.

67. Liao WT, Cui YM, Ding YQ: Expression and Significance of Bmi-1 PTEN and E-Cadherin in Colorectal Cancer. Chin J Clin Oncol 39: 559-563, 2012 (In Chinese). 